\title{
SYSTEM OF AUTOMATIC CONTROL OF THE LEVEL OF STEAM POWER GENERATORS ON THE BASIS OF THE REGULATION CIRCUIT WITH SMOOTHING OF THE SIGNAL
}

\author{
UMURzakova Dilnoza MaXaMadJonovna* \\ Department of Information Processing Systems and Management, \\ Tashkent State Technical University, 100097 Tashkent, Uzbekistan \\ Corresponding author: umurzakovadilnoz@gmail.com
}

(Received: 25th March 2020; Accepted: $3^{\text {rd }}$ September 2020; Published on-line: $4^{\text {th }}$ January 2021)

\begin{abstract}
The purpose of this article is to develop high-quality combined automatic control systems (ACS) for the water level in the drum of steam boilers of thermal power plants (TPPs), which can significantly improve the quality of regulation and increase the efficiency of TPPs in a wide range of load changes. To improve the quality of water level control in the drum of steam generators of nuclear power plants with a pressurized watercooled power reactor (PWPR), it is proposed to use a combined automatic control system based on a control loop with a correcting PI-controller tuned to a symmetrical optimum, with smoothing the reference signal and device compensation of the most dangerous internal and external measurable disturbances. A technique has been developed for assessing the impact of changes in the quality characteristics of transients of combined self-propelled guns by the water level in the drum of steam boilers and steam generators on the safety, reliability, durability, and efficiency of thermal power equipment of thermal power plants. Comparison was made of direct indicators of the quality of three ACS (typical and three-pulse, digital system with an observer state, and the proposed combined ACS). The simulation results of transients of the proposed and typical three-pulse selfpropelled guns confirmed the advantages of the first.
\end{abstract}

ABSTRAK: Artikel ini bertujuan bagi membina sistem kombinasi automatik (ACS) berkualiti tinggi bagi aras air dalam drum dandang stim tenaga terma logi kuasa (TPP). Ini dapat meningkatkan mutu peraturan dan meningkatkan kecekapan TPP secara signifikan dengan pelbagai perubahan beban. Bagi meningkatkan kualiti kawalan aras air dalam drum penjana wap loji kuasa tenaga nuklear dengan reaktor berpendingin air bertekanan (PWPR). Gabungan sistem kawalan automatik berdasarkan gelung kawalan dengan pembetulan PI telah dicadangkan dan diselaraskan simetri secara optimum, dengan melancarkan isyarat rujukan dan pembetulan peranti dari gangguan yang boleh diukur dari dalam dan luar. Satu teknik telah dibina bagi menilai kesan perubahan ciri kualiti transien gabungan berjentera pada aras air di tong dandang stim dan drum penjana wap pada keselamatan, kebolehpercayaan, ketahanan dan kecekapan peralatan tenaga terma loji janakuasa. Perbandingan dibuat pada kualiti tiga ACS (sistem digital khas dan tiga signal dengan keadaan pemerhati dan gabungan ACS yang dicadangkan). Hasil sistem simulasi transien yang dicadangkan dan tiga signal biasa berjentera mengesahkan kelebihan pada yang pertama.

KEYWORDS: combined automatic control system; steam boiler drum; steam generator; controller; adaptive system; heat power industry 


\section{INTRODUCTION}

Currently widespread in the field of automation, heat and power processes in thermal and nuclear power plants (TPPs and NPPs) received standard three-pulse automatic control systems (ACS). As a result of their wide distribution, the problem of "technical contradiction" arises between the speed and stability of the system. The existing ACS with the water level in the boiler drum and their modifications, which have become widespread at TPPs and NPPs, but significant load changes turned out to be insufficiently effective. An increase in the steam production of boilers, the parameters of superheated steam at the outlet of the latter, as well as the need for boilers to operate in the peak and half-peak parts of the electrical loads of the power system, actualizes the problem of a significant increase in the quality of water level control in the drum in the entire range of load variation of heat power facilities during deep disturbances.

A comparison of steam production technologies at TPPs and NPPs shows that they are similar to each other: in essence, the difference is that the reactor and the primary circuit take on the role of the furnace in the boiler of TPPs at nuclear power plants. Therefore, the schemes for automatic control and regulation of nuclear power units in general coincide with the schemes for regulating power units of TPPs. The similarity of steam and electricity production technologies at TPPs and NPPs leads to the similarity of their automatic control and regulation schemes. One of the main ACS of nuclear power plants that determine the safety and reliability of power units is self-propelled guns for the water level in the drum of the steam generator. Despite attempts to use single-pulse level control systems in the drum of a steam generator of nuclear power plants [1], typical three-pulse self-propelled guns have currently gained maximum popularity at thermal power plants and nuclear power plants, which cannot provide the required quality level maintenance in the drum under deep load changes [2].

To eliminate this drawback, it is proposed to use a combined self-propelled gun for objects without self-leveling with the allocation of an equivalent external disturbance [3], which is characterized by increased fluctuations in the flow rate of feed water when disturbed by the steam flow. In [4], it was proposed to use combined self-propelled guns with a limitation of the maximum value of the corrective action at the output of the equivalent external disturbance compensation device.

Steam generators of NPP with pressurized water power reactor (PWPR) are complex control objects, on the reliable operation of which safety depends and the reliability of the entire power plant. The main controllable parameter in the steam generator (SG) is the water level, which is subject to rigid requirements. Inaccurate maintenance of the water level in the steam generator drum leads to an increase in humidity steam, increases the wear of the turbine blade and reduces the power of the power unit. The control of the water level in the drums of boilers of TPP and SG of NPP is carried out by three-pulse ACS [5,6].

\section{RESEARCH METHODS}

A typical three-pulse ACS with the water level in the boiler drum has the following disadvantages:

- the presence of a static control error at the end of the transient process, first of all, when there is an external disturbance by the steam flow with the phenomenon of "level swelling"; 
- the presence of three measurement sensors (level, steam, and feed water consumption);

- large deviations of the water level in the boiler drum beyond the established limits with large load changes, which lead to the boiler shutdown by protection in case of overflow.

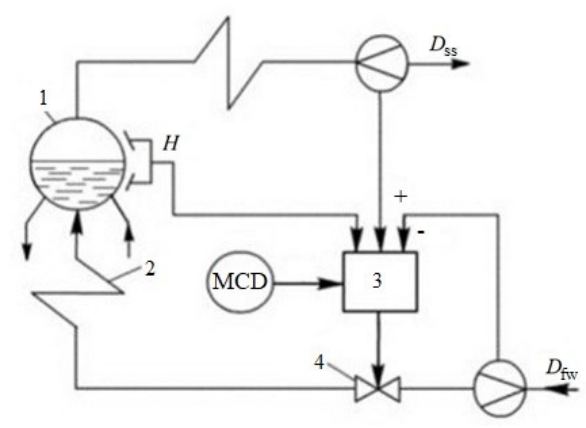

Fig. 1: Typical three-pulse ACS with water level in the drum: 1 - boiler drum; 2 water economizer; 3 - controller; 4 - regulating feed valve; MCD - manual control dial; $H$ - level water; $D_{f w}$ - consumption of feed water; $D_{s s}$ - superheated steam

flow rate.

The specified ACS under deep disturbances in the system does not provide the required quality regulation, which leads to unloading or shutdown of the power unit and economic losses [7].

To improve the quality of the control of the steam generator PGV-1000 level at NPP with PWPR a digital PI controller with one water level instead of three in the standard ACS, which ensures an improvement in the quality of control in the case of external and internal disturbances in comparison with the typical system [8]. In this regard, the task of further improving the quality of comparison with the optimal ACS with a state observer is based on express methods of structural and parametric optimization of dynamic systems of heat and power processes of NPP and TPP with using the principles of the theory of invariance [9]. One of the implementation options for such systems is shown in Fig. 2 [10].

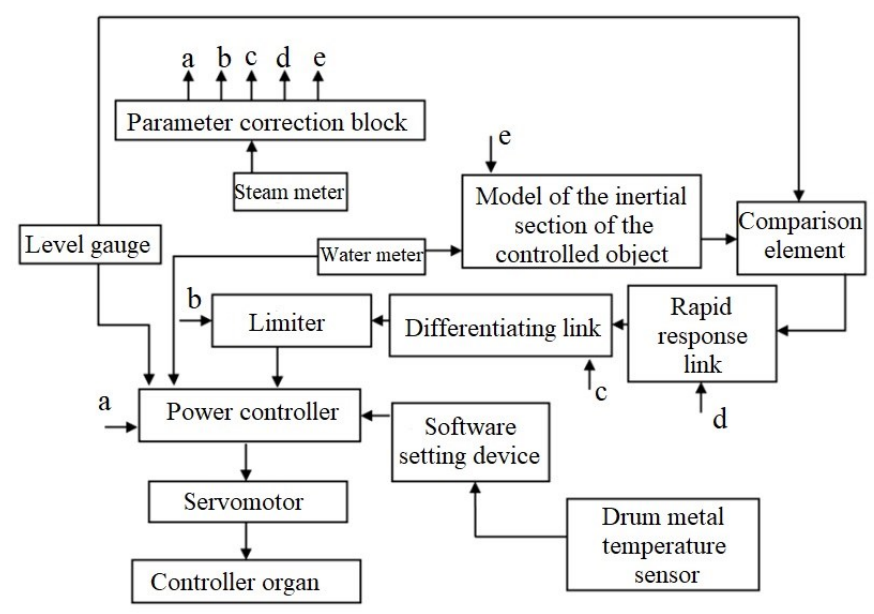

Fig. 2: Scheme of implementation of the combined ACS by the water level in the boiler drum. 
The specified combined ACS with the extraction of an equivalent external disturbance provides a decrease in the maximum dynamic error of regulation by the water level in the drum under external disturbance with steam consumption by $36 \%$ compared to a typical ACS with differentiator. In this case, the time for working out the disturbance with the steam consumption is $200 \mathrm{~s}$.

To further improve the quality of maintaining the water level in steam generators of TPPs based on standard controllers, it is proposed to use self-propelled guns based on a control loop with reference signal smoothing (Fig. 3). Designations adopted in Fig. 3: $y(t)$ , $y_{1}(t)$ - respectively, the main (water level in the drum) and intermediate (feed water flow) controlled values; $x_{s t 1}, x_{s t 2}$ - assignment of intermediate and main controlled quantities; $x_{s t 2}^{s}$ - smoothed setpoint to the correction knob; $x_{c}(t), x_{r}(t)$ - corrective and control effects; $f_{1}, f_{2}$ - internal and external disturbances; $k_{l e}$ - coefficient transmission; $e^{-\tau_{1} s}$ - pure lag; transfer functions: $W_{l e}(s)$ - leading site of the object; $W_{1}(s)$ - inertial section of the object; $W_{2}(s)-W_{3}(s)$ - the difference between the inertial link and the ideal integrating link, which describes the dynamics of the phenomenon of "swelling" of the water level with increasing steam flow from the steam generator; $W_{c d}^{f_{1}}(s), W_{c d}^{f_{2}}(s)$-compensation devices for measured internal and external disturbances.

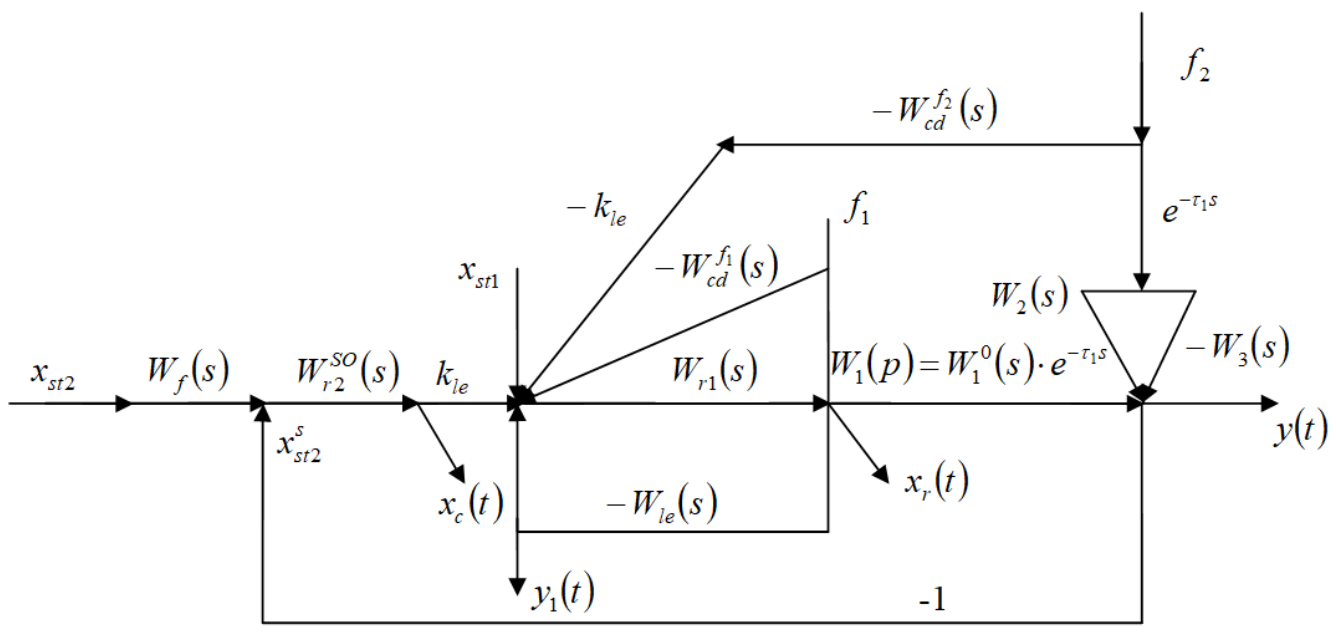

Fig. 3: Structural diagram of the combined PGV-1000 steam generator automatic level control system with a correcting PI controller tuned to a symmetrical optimum, with a smoothing of the reference signal.

The numerical values of the transfer functions developed by the combined ACS of the level of the steam generator PGV-1000 TPP with WWPR-1000 are shown in the structural diagram of the simulation in Fig. 4. 


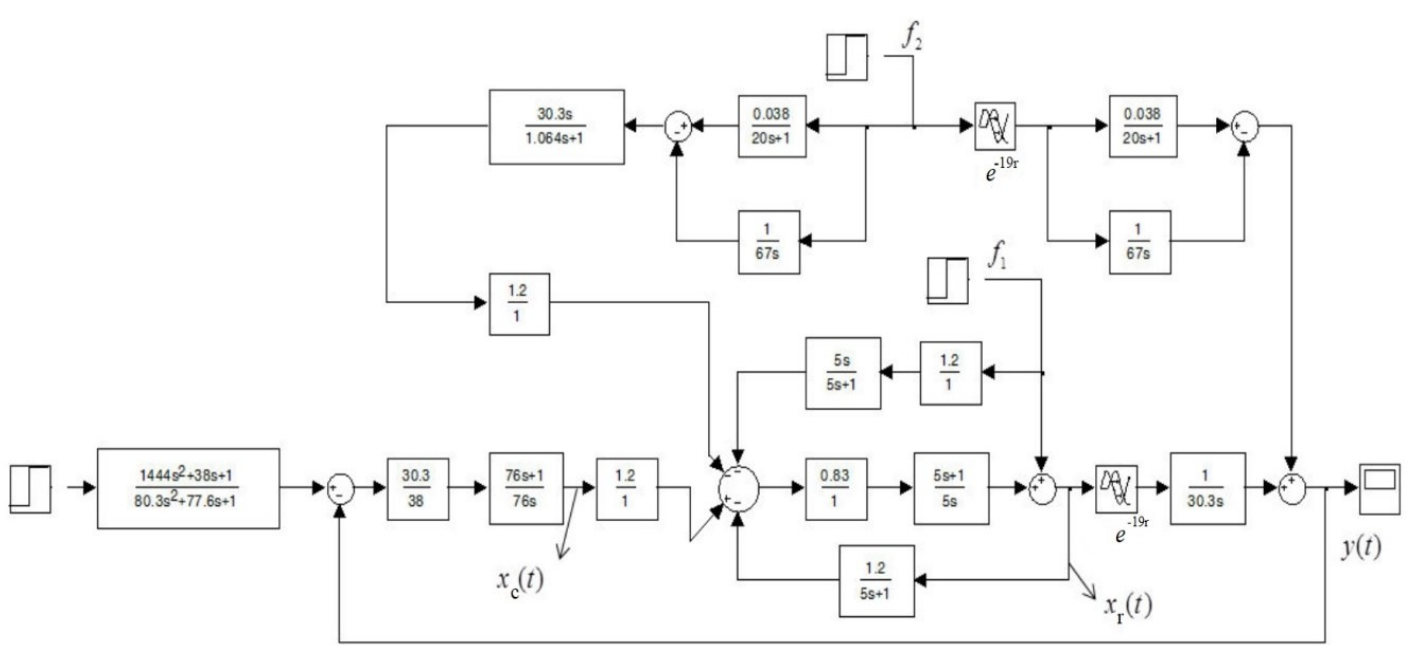

Fig. 4: Transient simulation modeling of combined ACS with a water level in the PGV-1000 drum with a PI controller tuned to a symmetric optimum with smoothing of the reference signal.

The following notation of transfer functions is accepted here:

- leading section:

$$
W_{l e}(s)=\frac{k_{l e}}{T_{l e} s+1}=\frac{1,2}{5 s+1} ;
$$

- inertial section:

$$
W_{1}(s)=W_{1}^{0}(s) \cdot e^{-\tau_{1} s}=\frac{e^{-19 s}}{30,3 s}
$$

- inertial link of the first order:

$$
W_{2}(s)=\frac{k_{2}}{T_{2} s+1}=\frac{0,038}{20 s+1} ;
$$

- ideal integrating link:

$$
W_{3}(s)=\frac{k_{2}}{T_{3} s}=\frac{1}{67 s}
$$

- stabilizing PI controller:

$$
W_{c 1}(s)=\frac{k_{1}\left(T_{I 1} s+1\right)}{T_{I 1} s}=\frac{0,83(5 s+1)}{5 s} ;
$$

- corrective PI controller:

$$
W_{c 2}(s)=\frac{k_{2}\left(T_{I 2} s+1\right)}{T_{I 2} s}=\frac{0,797(76 s+1)}{76 s} ;
$$

- smoothing filter:

$$
W_{f}(s)=\frac{4 \tau_{1}^{2} s^{2}+2 \tau_{1} s+1}{\left(4 \tau_{1} s+1\right)\left(T_{s t 2} s+1\right)}=\frac{1444 s^{2}+38 s+1}{80,3 s^{2}+77,06 s+1},
$$


where $T_{s t 2}-$ a dynamic tuning parameter aligning the order of the numerator and denominator of the filter transfer function;

- compensation devices for measured internal disturbance

$$
W_{c d}^{f_{1}}(s)=\frac{k_{D 1} T_{D 1} s}{T_{D 1} s+1}=\frac{1,2 \cdot 5 s}{5 s+1}
$$

- compensation devices for measured extreme external disturbance by steam flow:

$$
W_{c d}^{f_{2}}(s)=\left[W_{2}(s)-W_{3}(s)\right] \frac{T_{1} s}{T_{s t 3} s+1}=\left[\frac{0,038}{20 s+1}-\frac{1}{67 s}\right] \cdot \frac{30,3 s}{1,064 s+1},
$$

where $T_{s t 3}$ - a dynamic tuning parameter aligning the order of the numerator and denominator of the transfer differentiator of the device for compensating extreme external disturbances by the steam flow rate.

It is required to form such an ACS structure, which significantly (at times) will reduce the maximum permissible level control error when disturbed by the steam flow compared to a typical three-pulse ACS, to achieve complete invariance when working out the most dangerous measured internal disturbance, and also to eliminate large overshoot (up to $43.4 \%$ ) when working out the jump in task $x_{s t 2}$, inherent ACS with a correcting PI controller tuned to a symmetrical optimum [11].

In order to form the ACS structure that satisfies the given requirements, we will start by choosing the stabilization structure of the controller as the product of the inverse transfer function of the leading section and the transfer function of the open system in the form of an ideal integrating link taking into account (1) [12]:

$$
W_{r 1}(s)=\left[W_{l e}(s)\right]^{-1} \cdot W_{s t 1}^{O S(n=1)}(s)=\frac{T_{l e} s+1}{k_{l e} T_{s t 1}(s)}=\frac{5 s+1}{1,2 \cdot 5 s}=0,83 \frac{5 s+1}{5 s},
$$

where $T_{s t 1}=T_{l e}$ - parameter of dynamic adjustment of the stabilizing controller.

In this case, the internal circuit of the system with a stabilizing controller during the completion of task $x_{s t 1}$ can be replaced by a first-order inertial unit that plays the role of a quality criterion:

$$
W_{s t 1}(s)=\frac{1}{T_{s t 1} s+1}
$$

If between the output of the correction and the input of the stabilizing controllers there is an amplifier with the transmission coefficient $k_{a m}=k_{l e}$, then the corrective action $x_{c}(t)$ will be equal to the regulating $x_{r}(t)$. As a result, the dual-circuit system turns into a singleloop system with a correcting controller and an inertial section of the object (2). If, at the same time, we select and measure the most dangerous internal disturbance $f_{1}$ using an additional sensor, the output of which is connected to the input of the compensation device for this disturbance, then the ACS will have complete invariance with respect to $f_{1}$ if the following condition is satisfied [13]:

$$
W_{c d}^{f_{1}}(s) \cdot W_{r 1}(s)=1 .
$$


From where, taking into account (5), we obtain the transfer function of the compensation device for the measured internal disturbance in the form of a real differentiator:

$$
W_{c d}^{f_{1}}(s)=\frac{1}{W_{r 1}(s)}=\frac{T_{I 1} s}{k_{r 1}\left(T_{I 1} s+1\right)} .
$$

For high-quality testing of internal unmeasured disturbances, the dynamic adjustment of the correcting PI controller should be performed at a symmetrical optimum with respect to the transfer function of the object (2) [14]:

$$
\begin{aligned}
& T_{I 2}=4 \tau_{1}=76 s . \\
& k_{r 2}=\frac{1}{2 k_{i n} \tau_{1}}=\frac{30,3}{2 \cdot 19}=0,797 .
\end{aligned}
$$

At the same time, with the high-quality processing of internal disturbances, the graph of the transition characteristic for the water level in the drum of the steam generator in relation to the task at the entrance to the correcting controller will have the following direct quality indicators: the first time of regulation $t_{r 1}=3 \tau_{1}=3,1 \cdot 19=58,9 \mathrm{~s}$; time of final entry into the tolerance band $\pm 2 \% t_{r 2}=16,5 \cdot 19=313 s$; the maximum overshoot in this case will be $43.4 \%$ [15].

To eliminate overshoot and improve system performance when working out a task, a smoothing filter with a transfer function of this form is installed between the setter and the correction controller

$$
W_{f}(s)=\frac{4 \tau_{1}^{2} s^{2}+2 \tau_{1} s+1}{\left(4 \tau_{1} s+1\right)\left(T_{s t 2} s+1\right)}=\frac{1444 s^{2}+38 s+1}{80,3 s^{2}+77,06 s+1},
$$

where $T_{s t 2}$ - a dynamic filter setting parameter that aligns the order of the numerator and denominator of the filter transfer function (16), with a decrease in the numerical value which increases the ACS speed during mining $x_{s t 2}$.

To improve the quality of working out extreme external disturbances during a planned change in the load of the power unit, we measure the steam flow rate with an additional sensor, the output of which is fed to the input of the external disturbance compensation device, the dynamics of which is described by the transfer function $W_{c d}^{f_{2}}(s)$. The output of the compensation device through the amplifying link $k_{l e}$ is connected to the input of the stabilizing controller with the opposite sign. As a result, the invariance condition with a planned change in the load $y(t)$ with respect to the measured external disturbance takes the following form $[16,17]$ :

$$
W_{c d}^{f_{2}}(s) \cdot W_{1}^{0}(s) \cdot e^{-\tau_{1} s}=\left[W_{2}(s)-W_{3}(s)\right] \cdot e^{-\tau_{1} s} .
$$

Here, the delay link in the right-hand side of equality (17) is implemented programmatically in the automatic unit power generator, which, with a planned daily change in load, first generates the corresponding signal at the input to the external disturbance compensation device, and after the control action reaches the system output at time $t=\tau_{1}$, the power unit automatically switches to a different load level. In this case, the numerical value of $\tau_{1}$ is adjusted as a function of the load of the power unit [18]. 
Taking into account (2) and (17), the transfer function of the external disturbance compensation device, as well as the physical implementation condition, will take

$$
W_{c d}^{f_{2}}(s)=\left[W_{2}(s)-W_{3}(s)\right] \cdot \frac{T_{1} s}{T_{s t 3} s+1}
$$

where $T_{s t 3}$ - a parameter of dynamic adjustment of an external disturbance compensation device aligning the order of the numerator and denominator of the transfer function of the differentiator.

\section{RESULTS AND DISCUSSION}

Transient graphs combined by an ACS combined with the water level in the PGV-1000 drum with a PI controller tuned to a symmetrical optimum under basic influences confirming the achievement of specified requirements are shown in Fig. 5.
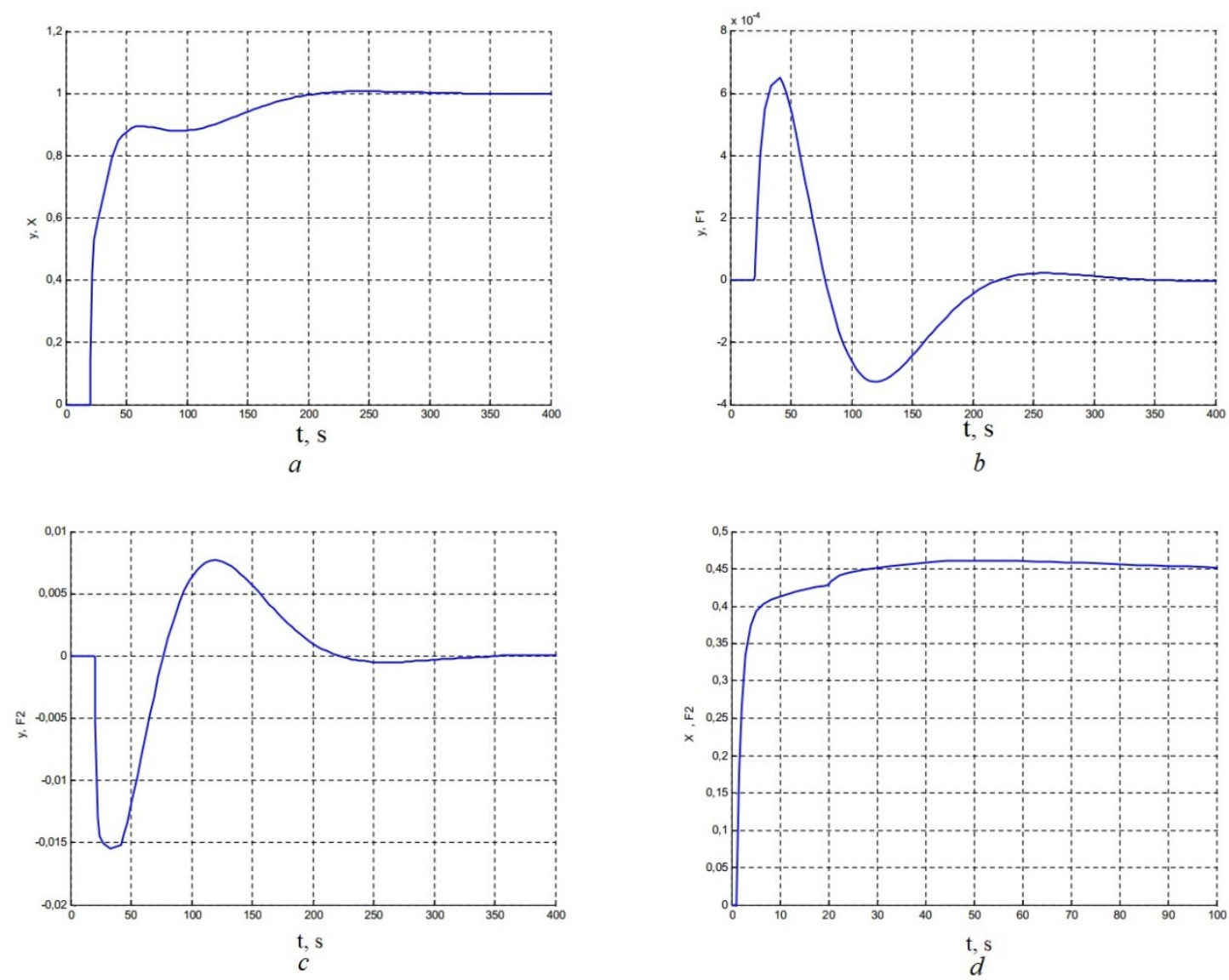

Fig. 5: Graphs of transient processes of combined ACS with the water level in the

PGV-1000 drum with the adjustment controller set to a symmetric optimum: a testing the jump of the setting action $x_{s t 2} ; \mathrm{b}$ - development of internal disturbance $f_{1}$

; c - development of external disturbance by steam flow $f_{2}^{*} ; \mathrm{d}$ - changes in the control action $x_{r}(t)$ during the development of an external disturbance by the steam flow rate; $\mathrm{t}$ - is time.

Three combined ACS of the water level in the drum of the PGV-1000 steam generator for a planned load change and complete invariance with respect to the most dangerous internal disturbance with the measurement of the external disturbance by the steam flow 
rate: ACS using the main feedback compensator during the processing of the driving signal, have been developed for steam generators of power units of PWPR TPPs with PWPR; ACS with smoothing the reference signal and using a PI controller tuned to a symmetric optimum (SO); ACS based on optimal controllers. In these ACSs, the structure and dynamic settings of the stabilizing controllers due to the additional amplifier at the output of the correcting controller ensure the equality of the correcting $x_{c}(t)$ and control $x_{r}(t)$ actions, as well as the complete invariance of the development of internal perturbations and invariance accurate to $\varepsilon$ when working out external perturbations by the steam flow rate. Direct indicators of the quality of transients of the two proposed ACSs in comparison with a typical three-pulse ACS and digital ACS with a state observer are shown in Table 1.

Table 1: Quality indicators of transients of the compared ACS

\begin{tabular}{ccccc}
\hline Name of ACS & $\Delta y / y_{N}$ & $\Delta H_{b}$ & $t_{r}, S$ & $\overline{X_{r}^{m}}$ \\
\cline { 2 - 5 } & 0,034 & 83,6 & 160 & 0,454 \\
\hline $\begin{array}{c}\text { typical three-pulse } \\
\text { ACS }\end{array}$ & 0,031 & 76,0 & 130 & $+0,61$ \\
$\begin{array}{c}\text { digital ACS with state } \\
\text { observer }\end{array}$ & 0,016 & 41,0 & 200 & $+0,46$ \\
$\begin{array}{c}\text { combined ACS with } \\
\text { signal smoothing and } \\
\text { the use of a PI } \\
\text { controller (SO) } \\
\text { combined ACS based } \\
\text { on optimal controllers }\end{array}$ & 0,024 & 61,5 & 75 & $+0,475$ \\
\hline
\end{tabular}

From the analysis of the data in Table 1 it follows that the proposed combined ACS provides the best direct quality indicators in relation to a typical three-pulse ACS, and digital ACS with a state observer. The following notation has been adopted here: $\Delta y / y_{N}$ - the relative deviation of the water level in the drum from the nominal; $\Delta H_{b}$-absolute deviation of water level $13 ; t_{r}$ - regulation time; $\overline{X_{r}^{m}}$ - the maximum value of the control impact.

\section{CONCLUSION}

The results of this research made it possible to formulate the following practical recommendations for improving the quality of drum water level control in steam boilers and steam generators:

- refinement of task $x_{s t 2}$ is carried out without overshoot. The control time is $200 \mathrm{~s}$ instead of $313 \mathrm{~s}$ without a smoothing filter.

- when working out the measured internal disturbance, the complete invariance of the ACS is achieved.

- the maximum dynamic level deviation in a combined ACS using a PI controller tuned to a symmetrical optimum is 0.016 relative units, which corresponds to $41 \mathrm{~mm}$ of water, which is 2 times less than in a typical three-pulse ACS.

- the maximum change in the controller action in the combined ACS decreased by $22.1 \%$ compared to the ACS with a state observer 
- the mathematical model for assessing the quality of ACS transient processes the water level for partial and complete load shedding of the boiler can be used to clarify the settings for the operation of technological protections without carrying out field tests of the systems.

\section{REFERENCES}

[1] Siddikov IX, Umurzakova DM, Bakhrieva HA. (2020) Adaptive system of fuzzy-logical regulation by temperature mode of a drum boiler. IIUM Engineering Journal, 21(1): 185192. https://doi.org/10.31436/iiumej.v21i1.1220.

[2] Siddikov IX, Umurzakova DM. (2019) Mathematical Modeling of Transient Processes of the Automatic Control System of Water Level in the Steam Generator, Universal Journal of Mechanical Engineering, 7(4): 139-146. doi: 10.13189/ujme.2019.070401.

[3] Siddikov IX, Umurzakova DM. (2019) Synthesis of Adaptive Control Systems of a Multidimensional Discrete Dynamic Object with a Forecasting Models. International conference on information science and communications technologies applications, trends and opportunities (ICISCT 2019). Tashkent University of information technologies named after Muhammad al-Khwarizmi. -Tashkent. 4-6 November, 2019. DOI: 10.1109 / ICISCT47635.2019.9012033

[4] Siddikov IX, Umurzakova DM. (2019) Neuro-fuzzy Adaptive Control system for Discrete Dynamic Objects. International conference on information science and communications technologies applications, trends and opportunities (ICISCT 2019). Tashkent University of information technologies named after Muhammad al-Khwarizmi. -Tashkent. 4-6 November, 2019. DOI: 10.1109/ICISCT47635.2019.9012027.

[5] Siddikov IX., Umurzakova DM. (2020) Fuzzy-logical Control Models of Nonlinear Dynamic Objects // Advances in Science, Technology and Engineering Systems Journal, Vol. 5, No. 4, 419-423 (2020). DOI: 10.25046/aj050449.

[6] Demchenko VA. (2001) Avtomatizacija i modelirovanie tehnologicheskih processov AJeS i TJeS. Odessa: Astroprint, $308 \mathrm{~s}$.

[7] Pletnev GP. (2007) Avtomatizacija tehnologicheskih processov i proizvodstv v teplojenergetike: uchebnik dlja studentov vuzov. M.: Izd. dom MJeI, $352 \mathrm{~s}$.

[8] Rotach, V. Ya. (2008) The Theory of Automatic Control. Moscow: Publishing House Moscow Power Engineering Institute, 396 p.

[9] Zhu X, Zhang H, Cao D, Fang Z. (2014) Robust control of integrated motor-transmission powertrain system over controller area network for automotive applications, Mechanical Systems and Signal Processing, 58: 15-28.

[10] Zulfatman, Rahmat MF. (2009) Application of self-tuning Fuzzy PID controller on industrial hydraulic actuator using system identification approach, International Journal on Smart Sensing and Intelligent Systems, 2(2): 246-261.

[11] Das S, Pan I, Halder K, Das S, Gupta A. (2013) LQR based improved discrete PID controller design via optimum selection of weighting matrices using fractional order integral performance index, Applied Mathematical Modelling: Simulation and Computation for Engineering and Environmental Systems, 37(6): 4253-4268.

[12] Gasbaoui B, Nasri A. (2012) A novel multi-drive electric vehicle system control based on multi-input multi-output PID controller, Serbian Journal of Electrical Engineering, 9(2): 279-291.

[13] Has Z, Muslim AH, Mardiyah NA. (2017) Adaptive-fuzzy-PID controller based disturbance observer for DC motor speed control, in Proceedings of the 2017 4th International Conference on Electrical Engineering, Computer Science and Informatics (EECSI), pp. 1-6, Yogyakarta, September.

[14] Hu S, Liang Z, Zhang W, He X. (2018) Research on the integration of hybrid energy storage system and dual three-phase PMSM Drive in EV, IEEE Transactions on Industrial Electronics, 65(8): 6602-6611. 
[15] Iplikci S. (2010) A comparative study on a novel model-based PID tuning and control mechanism for nonlinear systems, International Journal of Robust and Nonlinear Control, 20(13): 1483-1501.

[16] Kumar SMG, Deepak J, Anoop RK. (2010) PSO based tuning of a PID controller for a high performance drilling machine, International Journal of Computer Applications, 1(19): 12-18.

[17] Malwatkar GM, Khandekar AA, Nikam SD. (2011) PID controllers for higher order systems based on maximum sensitivity function, 2011 3rd International Conference on Electronics Computer Technology.

[18] Pelusi D. (2012) PID and intelligent controllers for optimal timing performances of industrial actuators, International Journal of Simulation: Systems, Science and Technology, 13(2): $65-71$. 